\title{
ANTI-RUTTING PERFORMANCE ANALYSIS OF ASPHALT MIXTURE WITH DIFFERENT NATURAL ASPHALT
}

\author{
Wentong HUANG, Guoyuan XU
}

School of Civil Engineering and Transportation, South China University of Technology (wthuang@scut.edu.cn)

\begin{abstract}
The modification mechanism and high temperature deformation law are obtained by the rutting test of the same matrix asphalt and aggregate gradation with different natural asphalt mixture. It proves that the anti-rutting performance of the asphalt mixture with Iran rock is close to that of SBS modified asphalt mixture.
\end{abstract}

Keywords: Natural Asphalt, Modification Mechanism, Mixture, Rutting Performance.

\section{INTRODUCTION}

With high speed development of our national economy, the highway was constructed on large-scale all around the country. Because of the overload and channelization traffic, polymer modified asphalt as a high performance asphalt material is widely used in highway construction. Asphalt modifier mainly includes SBS, SBR, PE, EVA, TLA, Gilsonite, BMA, etc, and their applied range from SMA to conventional asphalt concrete in whole road surfacing. The production of modified asphalt is a complex physical and chemical change process. To get good modification effect, the physical change should be given priority to in this process [1].

Asphalt modifier can obviously improve the high temperatures performance of the asphalt mixture, but the research in this aspect is not deep enough. And the performance comparison of different asphalt modifier is few appear in previous studies. This paper researched the modification mechanism and high temperature deformation law by the rutting test of the same matrix asphalt and aggregate gradation with different natural asphalt mixture.

\section{CHARACTERISTICS OF NATURAL ASPHALT}

Because natural asphalt does not contain paraffin, it will put this characteristics to the base asphalt in the recombination process when it is added to the base asphalt, and then reduce the harm of paraffin in asphalt, thus can obviously improve the stability of the asphalt mixture. Because of the strong absorption ability, natural asphalt can improve the wettability in stone surface. According to the test data, the absorption and anti-stripping ability of natural asphalt on silicate mineral, quartzite, limestone, kaolinite and silicoaluminate mineral is sev- 
eral times stronger than that of the base asphalt [2-4]. In general, natural asphalt has high softening point that is $150{ }^{\circ} \mathrm{C}$ above. Therefore, it as one kind modifier can obviously improve the anti-rutting performance and shear behavior under high temperature condition. At the same time, it also has strong anti-fracturing property in low temperature condition [5]. Natural asphalt mixes with base asphalt very easily. As the blending between asphaltic bases, natural asphalt and base asphalt have good compatibility and stability. The asphalt mixture modified by natural asphalt is very stability, and it has several advantages, such as no piled up requirements, needing no heating transportation, simple modification technology, simple construction technology, etc [6].

\section{HIGH TEMPERATURE PERFORMANCE OF ASPHALT MIXTURE MODIFIED BY NATURAL ASPHALT}

As a viscoelastic material, asphalt will be destroyed because of the excessive deformation under high temperature and heavy traffic conditions. With the temperature increases, asphalt shows a feature of changing from elastic body to plastic body. And its stiffness modulus reduces greatly, deformation increases significantly [7]. The basic physics-chemistry characteristic of natural asphalt is same as that of conventional asphalt. As a modifier, natural asphalt can improve the asphalt colloid properties and intermolecular forces mainly based hydrogen bond [8]. Natural asphalt contains minerals, it can make the modified asphalt shows some features, for example, viscosity and softening point increased, needle penetration decreased, thus improving the high temperature stability of asphalt mixture [9].

\section{RAW MATERIAL AND MIXTURE GRADATION}

\subsection{Raw material}

The test result of the A-70 asphalt and SBS (I-D) modified asphalt is shown as table 1 and table 2. The modifiers are Iran rock asphalt (Gilsonite), Buton rock asphalt, TLA lake asphalt, SBS modifier respectively. The aggregate is granite, and filler is limestone ore powder. The high temperature test result of different asphalt is shown as table 3 .

Table 1 Technical indicators of A-70 asphalt

\begin{tabular}{|c|c|c|c|c|c|c|c|c|c|c|c|c|c|}
\hline \multirow[b]{2}{*}{$\begin{array}{l}\text { Test } \\
\text { items }\end{array}$} & \multirow[b]{2}{*}{$\begin{array}{c}\text { Needle } \\
\text { penetration } \\
\text { at } 25^{\circ} \mathrm{C} \\
(0.1 \mathrm{~mm})\end{array}$} & \multirow[b]{2}{*}{$\begin{array}{l}\text { Needle } \\
\text { penetrat- } \\
\text { ion } \\
\text { indicator }\end{array}$} & \multirow[b]{2}{*}{$\begin{array}{l}\text { Soft- } \\
\text { ening } \\
\text { point } \\
\left({ }^{\circ} \mathrm{C}\right)\end{array}$} & \multirow[b]{2}{*}{$\begin{array}{l}\text { Ducti- } \\
\text { lity at } \\
10^{\circ} \mathrm{C} \\
(\mathrm{cm})\end{array}$} & \multirow[b]{2}{*}{$\begin{array}{l}\text { Den- } \\
\text { sity at } \\
15^{\circ} \mathrm{C} \\
\left(\mathrm{g} / \mathrm{cm}^{3}\right)\end{array}$} & \multirow[b]{2}{*}{$\begin{array}{l}\text { Solu- } \\
\text { bility } \\
(\%)\end{array}$} & \multirow[b]{2}{*}{$\begin{array}{l}\text { Flash } \\
\text { point } \\
\left({ }^{\circ} \mathrm{C}\right)\end{array}$} & \multirow[b]{2}{*}{$\begin{array}{c}\text { Wax- } \\
\text { content } \\
(\%)\end{array}$} & \multirow[b]{2}{*}{$\begin{array}{l}\text { Dyna- } \\
\text { mic } \\
\text { viscosity } \\
\text { at } 60^{\circ} \mathrm{C} \\
(\mathrm{Pa} \cdot \mathrm{s})\end{array}$} & \multirow[b]{2}{*}{$\begin{array}{c}\text { Apparent } \\
\text { viscosity } \\
\text { at } 135^{\circ} \mathrm{C} \\
\quad(\mathrm{Pa} \cdot \mathrm{s})\end{array}$} & \multicolumn{3}{|c|}{ RTFOT test residue } \\
\hline & & & & & & & & & & & $\begin{array}{c}\text { Mass } \\
\text { change } \\
(\%)\end{array}$ & $\begin{array}{l}\text { Needle } \\
\text { penetra- } \\
\text { tion ratio } \\
\text { at } 25^{\circ} \mathrm{C} \\
(\%)\end{array}$ & $\begin{array}{l}\text { Duct- } \\
\text { ility } \\
\text { at } \\
10^{\circ} \mathrm{C} \\
(\mathrm{cm})\end{array}$ \\
\hline $\begin{array}{l}\text { Test } \\
\text { result }\end{array}$ & 65 & -1.15 & 48.6 & 65.2 & 1.034 & 99.8 & 289 & 1.81 & 254 & 0.40 & -0.14 & 69.2 & 9.5 \\
\hline
\end{tabular}


Table 2 Technical indicators of SBS modifier

\begin{tabular}{|c|c|c|c|c|c|c|c|c|c|c|c|}
\hline \multirow[b]{2}{*}{$\begin{array}{c}\text { Test } \\
\text { items }\end{array}$} & \multirow[b]{2}{*}{$\begin{array}{c}\text { Needle } \\
\text { penetration } \\
\text { at } 25^{\circ} \mathrm{C} \\
(0.1 \mathrm{~mm})\end{array}$} & \multirow[b]{2}{*}{$\begin{array}{c}\text { Needle } \\
\text { penetration } \\
\text { indicator }\end{array}$} & \multirow[b]{2}{*}{$\begin{array}{l}\text { Soften- } \\
\text { ing point } \\
\left({ }^{\circ} \mathrm{C}\right)\end{array}$} & \multirow[b]{2}{*}{$\begin{array}{l}\text { Ducti- } \\
\text { lity at } \\
5^{\circ} \mathrm{C} \\
(\mathrm{cm})\end{array}$} & \multirow[b]{2}{*}{$\begin{array}{l}\text { Density } \\
\text { at } 15^{\circ} \mathrm{C} \\
\left(\mathrm{g} / \mathrm{cm}^{3}\right)\end{array}$} & \multirow[b]{2}{*}{$\begin{array}{l}\text { Solubi } \\
\text {-lity } \\
(\%)\end{array}$} & \multirow[b]{2}{*}{$\begin{array}{l}\text { Flash } \\
\text { point } \\
\left({ }^{\circ} \mathrm{C}\right)\end{array}$} & \multirow[b]{2}{*}{$\begin{array}{l}\text { Apparent } \\
\text { viscosity } \\
\text { at } 135^{\circ} \mathrm{C} \\
(\mathrm{Pa} \cdot \mathrm{s})\end{array}$} & \multicolumn{3}{|c|}{ RTFOT test residue } \\
\hline & & & & & & & & & $\begin{array}{c}\text { Mass } \\
\text { change } \\
(\%)\end{array}$ & $\begin{array}{c}\text { Needle } \\
\text { penetration } \\
\text { ratio at } 25^{\circ} \mathrm{C} \\
(\%)\end{array}$ & $\begin{array}{c}\text { Ductility } \\
\text { at } 5^{\circ} \mathrm{C} \\
\text { (cm) }\end{array}$ \\
\hline $\begin{array}{l}\text { Test } \\
\text { result }\end{array}$ & 54 & 0.05 & 82.6 & 28.2 & 1.032 & 99.9 & 297 & 2.50 & -0.15 & 80.7 & 20.1 \\
\hline
\end{tabular}

Table 3 High temperature technical indicators of different asphalt

\begin{tabular}{|c|c|c|c|c|c|}
\hline Test items & A-70 asphalt & $\begin{array}{l}85 \% \text { A-70 asphalt } \\
+15 \% \text { Iran rock } \\
\text { asphalt }\end{array}$ & $\begin{array}{l}75 \% \text { A-70 asphalt } \\
+25 \% \text { Buton } \\
\text { rock asphalt }\end{array}$ & $\begin{array}{l}67 \% \text { A-70 asphalt } \\
+33 \% \text { TLA lake } \\
\text { asphalt }\end{array}$ & $\begin{array}{c}\text { SBS modified } \\
\text { asphalt }\end{array}$ \\
\hline $\begin{array}{c}\text { Softening point } \\
\left({ }^{\circ} \mathrm{C}\right)\end{array}$ & 48.6 & 68.2 & 51.3 & 54.5 & 80.6 \\
\hline
\end{tabular}

\subsection{Mixture gradation}

The aggregate gradation of asphalt mixture adopts $\mathrm{AC}-13 \mathrm{C}$, and its composition is shown as table 4 .

Table 4 Gradation composition of AC-13C

\begin{tabular}{ccccccccccc}
\hline & \multicolumn{7}{c}{ Quality percentage (\%) through following screen (mm) } \\
\cline { 2 - 10 } Gradation type & 16 & 132 & 95 & 4.75 & 236 & 1.18 & 0.6 & 03 & 0.15 & 0.075 \\
\hline Gradation cap & 100 & 100 & 85 & 68 & 50 & 38 & 28 & 20 & 15 & 8 \\
Gradation floor & 100 & 90 & 68 & 38 & 24 & 15 & 10 & 7 & 5 & 4 \\
Target gradation & 100.0 & 97.7 & 71.8 & 39.2 & 29.4 & 22.8 & 18.2 & 13.5 & 9.3 & 6.4 \\
\hline
\end{tabular}

\subsection{Mixture configuration scheme}

According to the uniform aggregate gradation, five kinds of asphalt mixture are made up by using natural asphalt: (A) AC-13C base asphalt mixture (A-70 asphalt), the optimum asphalt content is 4.8\%; (B) Iran rock modified asphalt AC-13C mixture (85\% A-70 asphalt + $15 \%$ Iran rock asphalt), the optimum asphalt content is $4.9 \%$; (C) Buton rock modified asphalt AC-13C mixture (75\% A-70 asphalt $+25 \%$ Buton rock asphalt), the optimum asphalt content is 4.9\%; (D) TLA lake modified asphalt AC-13C mixture (67\% A-70 asphalt $+33 \%$ TLA lake asphalt), the optimum asphalt content is 5.3\%; (E) SBS modified asphalt AC-13C mixture (SBS modified asphalt), the optimum asphalt content is $4.9 \%$. The physical-mechanical indexes of the mixture with different natural asphalt are shown as table 5, and the results of rutting tests are shown as table 6. 
Table 5 Marshall test results of asphalt mixture

\begin{tabular}{|c|c|c|c|c|c|}
\hline \multirow{2}{*}{ items } & \multicolumn{5}{|c|}{ Number } \\
\hline & A & B & $\mathrm{C}$ & $\mathrm{D}$ & $\mathrm{E}$ \\
\hline Asphalt content (\%) & 4.8 & 4.9 & 4.9 & 5.3 & 4.9 \\
\hline Bulk density $\left(\mathrm{g} / \mathrm{cm}^{3}\right)$ & 2.427 & 2.432 & 2.423 & 2.418 & 2.423 \\
\hline Porosity (\%) & 3.5 & 4.3 & 4.1 & 4.7 & 4.1 \\
\hline $\begin{array}{c}\text { Voids in mineral aggregat } \\
\qquad(\%)\end{array}$ & 14.9 & 15.3 & 14.6 & 16.8 & 14.7 \\
\hline Asphalt saturation (\%) & 76.1 & 71.9 & 71.9 & 71.7 & 71.8 \\
\hline Stability (kN) & 10.31 & 15.39 & 10.90 & 12.81 & 11.70 \\
\hline Flow value $(0.1 \mathrm{~mm})$ & 36.11 & 28.5 & 30.55 & 25.90 & 26.1 \\
\hline
\end{tabular}

Table 6 Results of rutting tests

\begin{tabular}{cccccc}
\hline & \multicolumn{5}{c}{ Number } \\
\cline { 2 - 6 } Items & $\mathrm{A}$ & $\mathrm{B}$ & $\mathrm{C}$ & $\mathrm{D}$ & $\mathrm{E}$ \\
\hline \multirow{2}{*}{$\begin{array}{c}\text { Dynamic stability } \\
\text { (times/mm) }\end{array}$} & 1307 & 6002 & 3578 & 3628 & 6219 \\
Total deformation (mm) & 4.280 & 1.774 & 2.567 & 3.033 & 1.783 \\
\hline
\end{tabular}

\section{ANALYSIS OF THE TEST RESULTS}

According to the table 3, the softening point of the mixture with natural asphalt is improved all. The softening point of the SBS modified asphalt mixture is the highest, Iran rock modified asphalt followed. Iran rock modified asphalt softening point has exceeded the requirements of SBS (I-D) modified asphalt in "Technical specifications for construction of highway asphalt pavements" (JTG F40-2004) in China.

According to the table 5, the Marshall stability of the mixture with natural asphalt is improved obviously. The Marshall stability of the Iran rock modified asphalt mixture is the highest, and that of the Buton rock modified asphalt mixture is the lowest.

On the basis of the table 6 , the rutting test dynamic stability of the mixture with natural asphalt is improved obviously, too. The dynamic stability of the Iran rock modified asphalt mixture is 6002 times $/ \mathrm{mm}$, which is close to that of the SBS modified asphalt mixture, and is higher than that of the A-70 asphalt mixture by $359.2 \%$. The high-temperature stability of the Iran rock modified asphalt mixture is the best in all natural asphalt.

\section{CONCLUSIONS}

As a modifier, natural asphalt can effectively improve the surface adhesion of aggregate, and it is compatible with asphalt. The high temperature stability of the mixture modified by natural asphalt is improved obviously. The anti-rutting performance of the Iran rock modi- 
fied asphalt mixture is close to that of SBS modified asphalt mixture. Therefore, the Iran rock asphalt has a wonderful prospect in engineering.

\section{Acknowledgements}

This work is funded by the Natural Science Foundation of China (No.51078151).

\section{REFERENCES}

[1] Min HUA, "Study on modification mechanism of natural asphalt to base asphalt", Master's degree paper of Changan University, China, 2008.

[2] Burrell H, "Gilsonite information bulletin, polymer handbook", 2nd ed., wiler-inter Science, New York, 1975.

[3] Baldassare J E, Romagosa E E, “Gilsonite resin-a modifier for high stability pavementsEXPO on asphalt”, 7TH AAPA international asphalt conference, Brisbane, Australia, 7-11 August, 1988.

[4] Donna Harmelink S, “Gilsonite, an asphalt modifier", Colorado department of transportation, March, 1992.

[5] Asphalt concrete with gilsonite, state of ohio department of transportation supplemental specification 857, July 19, 2002.

[6] Fengling HE, Jie WANG, Jianming DING, "Research on performance of ZIGLER gilsonite modified asphalt mixtures", J. Highway, 12, 149-155, 2005.

[7] Yingmei YIN, Xiaoning ZHANG, "Research on high temperature rheological characteristics of asphalt mastics with Indonesian Buton Rock asphalt (BRA)", J. Journal of Wuhan University of Technology, 32(7), 85-89, 2010.

[8] Loeber L, Sutton O, Morel J, et al, "New direct observations of asphalts and asphalt binders by scanning electron microscopy and atomic force microscopy", J. Journal of Microscopy, 182, 32-39, 1996.

[9] Henglong ZHANG, Jianying YU, Qigang LI et al, “A Study on Properties and Mechanism of TLA Modified Asphalt”, J. Highway, 3, 121-125, 2010. 